Kesuma, S. (2018). Jilbab dan Reproduksi Identitas Mahasiswi Muslimah di Ruang Publik. MUKADIMAH, $1(2), 139-151$.

\title{
Jilbab dan Reproduksi Identitas Mahasiswi Muslimah di Ruang Publik
}

\author{
Sapta Kesuma \\ Prodi Pendidikan Pancasila dan Kewarganegaraan, FKIP - UISU \\ sapta.kesuma@fkip.uisu.ac.id
}

\begin{abstract}
ABSTRAK
Artikel ini mengulas persoalan perilaku pemakaian Jilbab di kalangan mahasiswi muslimah di ruang publik dan hubungannya dengan reproduksi identitas bagi yang memakainya. Jilbab telah mengalami pergeseran makna dari sebuah perintah agama Islam untuk menutup aurat perempuan menjadi pakaian yang mencerminkan berbagai identitas pemakainya. Jilbab dipakai dengan berbagai macam cara dan gaya oleh kalangan mahasiswi muslimah yang dipengaruhi oleh perkembangan dakwah Islam dan tren busana. Terdapat tiga kelompok pemakai Jilbab yang berhasil diidentifikasi di lingkungan kampus UISU dan UIN-SU, yaitu muslimah fenomenal, muslimah toleran, dan muslimah fashionable. Perilaku pemakai Jilbab di kedua kampus tersebut menunjukkan perbedaan. Kelompok muslimah fenomenal dominan di UIN-SU dan kelompok muslimah fashionable dominan di UISU, sedangkan dominasi muslimah toleran di UISU mengungguli UIN-SU. Identitas yang direproduksi oleh ketiganya disebut sebagai identitas hibrid yang ditampilkan ditentukan oleh pandangan agama dan motif berpakaian yang dikonstruksi oleh budaya dan lingkungan di sekitarnya. Jilbab tidak hanya sekadar berfungsi sebagai pakaian khas muslimah, melainkan juga berfungsi menampilkan simbol-simbol dan karakter pemakainya.
\end{abstract}

Kata kunci: Jilbab, reproduksi identitas, mahasiswi muslimah, ruang publik.

\section{PENDAHULUAN}

Fenomena pemakaian Jilbab sebagai sebuah tren di kalangan perempuan muslimah telah memuncak dalam satu dekade terakhir. Pemakai Jilbab terus bertambah terutama di kalangan mahasiswi muslimah di daerah-daerah mayoritas penganut agama Islam. Di kampus-kampus bernuansa Islam, Jilbab yang digunakan oleh mahasiswinya dipandang sebagai suatu identitas dan harga diri mutlak. Padahal masa-masa sebelumnya, pemakaian Jilbab di lingkungan lembaga pendidikan selalu diperdebatkan. Tentu masih melekat dalam memori masyarakat Indonesia yang menjadi pelajar atau mahasiswa sebelum dekade 2000-an. Pada masa itu perempuan muslim berpenampilan rambut terbuka adalah suatu hal yang biasa, bahkan pelajar perempuan tidak dianjurkan memakai penutup kepala sejenis kerudung, kecuali topi pelajar. Pas 
foto yang masih melekat di buku rapor dan ijazah atau foto-foto koleksi keluarga tempo dulu dapat dijadikan bukti sejarah bahwa kerudung dan Jilbab masih berupa sebuah pilihan alternatif kaum perempuan muslimah. Kemudian situasi berubah pada dekade 1990-an seiring membesarnya aspirasi masyarakat terhadap pemakaian Jilbab. Anjuran pemakaian Jilbab di lingkungan lembaga pendidikan baru dimulai pada tahun 1991, ketika pemerintah mengeluarkan SK No. 100 tentang pembolehan penggunaan jilbab di setiap lembaga pendidikan (Ahmadi \& Yohana, 2007). Setelah itu, Jilbab boleh dipakai oleh perempuan muslimah tanpa ada larangan baik di sekolah maupun di kampus-kampus. Bahkan kebebasan pemakaian Jilbab meluas menembus batas-batas ruang sosial. Pegawai kantor, ibu rumah tangga, pedagang, hingga artis dijangkiti tren Jilbab.

Selain dipandang trendy, Jilbab balakangan ini mampu menumbuhkan sektor baru dalam perekonomian Indonesia. Ia bukan lagi sekadar selembar kain penutup kepala, melainkan telah didesain, dimodifikasi, diberi merek, diiklankan, dan dikomersialkan ke khalayak. Produsen-produsen baru spesialis busana muslim menjamur dan bersaing memasarkan produk Jilbab mereka. Banyak pula kalangan artis skala nasional yang meramaikan bisnis busana muslim di Indonesia.

Secara umum ada dua jenis pemakai Jilbab di Indonesia. Pertama adalah pemakai Jilbab dari kalangan gerakan Islamis. Ada gerakan yang meluas dari kampus ke kampus Islam yang kemudian mempengaruhi proses kampanye Jilbab di kalangan mahasiswi muslimah. Secara simbolik gerakan itu dapat ditafsirkan sebagai upaya identifikasi diri di tengah krisis identitas yang melanda kalangan pemuda (Rais, 1991). Jenis pertama dapat dikenali dari penampilannya yang biasanya memakai Jilbab berukuran lebih lebar dari biasanya, baju gamis, longdress lebar dan rok, serta baju atasan serba lebar, kaos kaki, tidak jarang pula memakai cadar. Ciri khas jenis pertama sangat mewakili simbol-simbol keislaman, kesalehan, kesopanan, fundamentalis, konservatif, militan, dan anti-mainstream. Jenis kedua adalah pemakai Jilbab dari kalangan modernis, kawula muda, mengikuti perkembangan tren busana, dan tampak mewakili simbol-simbol kebebasan, modern, trendy, kekinian, dan sebagainya. Jenis kedua dapat dikenali dari penampilannya yang biasanya memakai Jilbab berukuran lebih kecil (kerap dililitkan ke leher), baju dan celana casual yang ketat mengikuti lekuk tubuh, dilengkapi aksesoris dan rias wajah yang atraktif. Ciri khas jenis kedua tersebut adalah bentuk ekspresi kawula muda berpandangan lebih fleksibel terhadap selera berbusana dengan kewajiban menutup aurat, namun secara subjektif tetap dinilai layak dan tidak kampungan (Al-Ghifari, 2004).

Permasalahan kemudian muncul ketika perintah agama dibenturkan dengan selera memakai Jilbab yang terkesan modis, kekinian, elok, fashionable, namun tetap diupayakan Islamis. Belum lagi bentuk dan model Jilbab semakin bervariasi sesuai kreativitas pada Jilbabers. Pemahaman yang keliru dalam menyelaraskan antara perintah agama dan tren busana kerap ditemui melanda 
remaja perempuan di Indonesia, dalam konteks pembahasan ini adalah mahasiswi muslimah. Mengagetkan bila model berpakaian yang dikenal dengan istilah Jilboobs berkembang menjadi fenomena yang tidak dapat dikontrol oleh masyarakat. Sikap apatis masyarakat juga yang mengakibatkan model berpakaian ala Jilboobs dipandang sebagai tren oleh remaja putri. Jilboobs adalah gaya berpakaian berjilbab tetapi seakan-akan tidak mengenakannya, berpakaian ketat namun menampakkan bentuk tubuh, terutama bagian payudaranya yang tidak tertutup kain Jilbab. Fenomena ini dipandang oleh (Hamidah \& Syadzali, 2016) sebagai suatu tanda yang merupakan konotasi negatif dalam fungsi Jilbab. Karena arti Jilboobs sendiri telah mengalami pergeseran dari makna Jilbab yang sesungguhnya. Praktik penggunaan Jilbab yang fashionable dan fenomena Jilboobs sangat identik dengan ciri kehidupan mahasiswi muslimah di ruang publik, yaitu lingkungan kampusnya.

Nancy J. Smith-Hefner mengatakan bahwa sejak tahun 1990 Jilbab sudah mulai digunakan oleh mahasiswi di perguruan tinggi di kota-kota kosmopolitan. Di kampus UGM Yogyakarta misalnya, Hefner menemukan data bahwa pemakai Jilbab pada tahun 1970 hanya 3\% dan pada tahun 2002 meningkat drastis hingga 60\% (Smith-Hefner, 2007). Selain itu menurut Turmudi bahwa penyebaran tren Jilbab jauh lebih efektif jika diorganisasikan melalui mahasiswa karena dapat dipastikan bahwa dengan adanya penyebarluasan tersebut nampaknya dapat memperkuat religiusitas, khususnya dalam implementasi jilbab sebagai pakaian sehari-hari (Turmudi, 2016). Eveline Ramadhani menemukan bahwa pengguna Jilbab yang menjamur di perguruan tinggi mempunyai identitas-identitas tertentu bagi masingmasing organisasi sekaligus dapat dimaknai sebagai representasi simbolis dalam pergaulan dan konsolidasi gerakan-gerakan yang ada di perguruan tinggi (Ramadhini, 2017). Jilbab ternyata digunakan bukan hanya karena komitmen teologis semata, namun juga karena konformitas yang dilakukan oleh individu agar dapat diterima secara sosial oleh tiap varian Islam.

\section{METODE DAN FOKUS PENELITIAN}

Artikel ini merupakan hasil dari kajian pustaka dan observasi terhadap kondisi nyata penggunaan Jilbab di kalangan mahasiswi muslimah di Medan. Observasi dilakukan di dua universitas ternama yang berbasis Islam di Medan, yaitu Universitas Islam Sumatera Utara (UISU) dan Universitas Islam Negeri Sumatera Utara (UIN-SU) selama semester ganjil 2017/2018. Metode penelitian yang digunakan dalam artikel ini adalah deskriptif-kualitatif.

\section{KERANGKA TEORETIK DAN KONSEPTUAL}

Konsep identitas menurut Berger dan Luckmann adalah sebuah unsur kunci dari kenyataan subjektif yang secara langsung berhubungan dengan masyarakat secara dialektif. Identitas dibentuk oleh proses-proses sosial. Begitu ia memperoleh wujudnya (pola identitasnya), ia dibentuk, dipelihara, dimodifikasi, bahkan dibentuk ulang oleh hubungan-hubungan sosial. Proses sosial yang terlibat dalam membentuk dan mempertahankan identitas juga 
ditentukan oleh struktur sosial, dan struktur sosial juga dibentuk oleh sejarah manusia (kebudayaan) yang tidak menafikan identitas masing-masing individu dan identitas tertentu. Sederhananya identitas dalam pandangan Berger berada pada dua konstruksi, yaitu tataran identitas secara personal dan identitas secara kolektif. Identitas merupakan suatu proses dialektika antara diri dan dunia yang sosio-kultural. Dengan demikian, di belakang identitas sosial terdapat identitas tertentu yang bersifat parsial. Berger menegaskan bahwa kasus-kasus individual lebih spesifik dan berkaitan dengan aspek psikologis (Berger \& Luckmann, 2013).

Selain itu, menurut Jenkins identitas adalah suatu cara bagaimana individu dan kelompok membedakan relasi sosialnya terhadap individu dan kelompok lainnya. Identitas dapat diklasifikasikan menjadi tiga hal, yaitu: (1) Primary identity, yaitu bagaimana individu atau kelompok mendefinisikan identitasnya; (2) Public image dan self image, yaitu bagaimana individu atau kelompok menunjukkan identitas dirinya; dan (3) Group identification dan categorisation, yaitu bagimana suatu identitas dikonstruksi secara kolektif melalui kekuasaan dan politik (Jenkins, 2008). Sementara itu, menurut Castells identitas hanya dapat menjadi identitas ketika aktor-aktor sosial menginternalisasikannya dan merekonstruksi makna di sekitarnya. Identitas berperan dan mengorganisasi suatu makna oleh para aktor berupa identifikasi simbolik serta memiliki tujuan tertentu. Castells membagi identifikasi menjadi, yaitu: (1) Identitas legitimasi, yaitu identitas yang dibentuk oleh aktor sosial ketika berhadapan dengan institusi dominan; (2) Identitas resisten, yaitu identitas yang digunakan dengan institusi dominan; (3) Identitas proyek, suatu identitas yang kedudukannya dibangun kembali secara lebih baru di dalam masyarakat (Castells, 2010).

Jilbab dapat dilihat sebagai respresentasi simbol yang ditampilkan oleh individu terhadap masyarakatnya secara interaksionisme simbolik. Menurut George Herbert Mead (Ritzer \& Goodman, 2003) suatu masyarakat terdapat simbol-simbol yang saling memengaruhi dan berinteraksi secara sosial. Simbol tersebut digunakan sebagai sesuatu yang direpresentasikan. Selain itu, simbol juga digunakan oleh individu untuk memberitahukan sesuatu tentang dirinya sendiri kepada khalayak. Mead memaparkan bahwa realitas sosial merupakan proses yang berlangsung terus-menerus dan bukan sesuatu yang statis. Manusia pada dasarnya memiliki persepsi (mind) dalam mengartikan dirinya (self) dengan interaksinya bersama orang lain atau masyarakatnya (society).Dengan demikian Jilbab menjadi identitas sosial dan representasi simbolik yang sangat berkaitan dengan suatu dimensi dari kenyataan yang mempunyai relevansi subjektif paling besar dan paling berkesinambungan bagi semua individu.

\section{HASIL DAN PEMBAHASAN}

Hakikat Jilbab 
Jilbab/hijab/kerudung pada dasarnya sudah sejak lama dikenal sebelum agama Islam diturunkan, namun dengan esensi yang berbeda. Jilbab telah digunakan terutama oleh kaum perempuan penganut agama-agama samawi yang taat. Secara etimologi, kata Jilbab (bentuk tunggal) berasal dari bahasa Arab, "Jalabib" (bentuk jamak) dan akar katanya yaitu "Jalaba" yang berarti menghimpun dan membawa. Jilbab merujuk pada pakaian yang dipakai oleh kaum perempuan Arab pada zaman pra-Islam, selain juga dipakai oleh kaum perempuan non-Arab. Sementara itu, secara istilah Jilbab memiliki arti antara lain: (1) pakaian yang lapang dan dapat menutupi bagian anggota tubuh wanita (auratnya) kecuali muka dan kedua telapak tangan sampai pergelangan tangan; (2) dalam al-Qur'an, Jilbab berarti sejenis baju kurung yang lapang, yang dapat menutupi kepala, muka, dan dada; (3) Ensiklopedi Hukum Islam mendefinisikan Jilbab adalah sejenis pakaian kurung yang longgar yang dilengkapi dengan kerudung yang menutupi kepala, leher, dan dada (Sidiq, 2012). Namun Jilbab juga diterjemahkan berbeda oleh para ulama. Misalnya ada pendapat ulama yang mengharamkan atau memakruhkan perampuan membuka muka dan dua telapak tangan di hadapan yang bukan mahram. Ada pula pendapat yang mewajibkan menutup muka dengan bercadar. Thabataba'i misalnya mengartikan Jilbab sebagai pakaian yang menutupi seluruh badan atau kerudung yang menutupi kepala dan wajah perempuan. Menurut alQurthubi, Jilbab adalah sehelai kain yang menutupi badan yang lebih luas daripada selendang. Sedangkan Ibnu Katsir menyarankan Jilbab itu ditutupkan ke badan di atas selendang. Ibnu Abbas mengartikan Jilbab sebagai al-rida' (mantel) yang menutup tubuh dari atas hingga ke bawah. Pendapat lainnya mengartikan Jilbab sebagai mula'ah (baju kurung) atau al-qamish (baju gamis) yang menutupi tubuh wanita (Sidiq, 2012). Ibnu 'Asyur mengartikan Jilbab sebagai pakaian yang lebih kecil dari jubah tetapi lebih besar dari kerudung atau penutup wajah yang dipakai oleh perempuan di atas kepala dan terulur kedua sisi kerudung itu melalui pipi hingga ke bahu belakangnya. Model jilbab bisa saja bervariasi sesuai selera yang mengikuti adat kebiasaan, tetapi tujuan yang dikehendaki sesuai dalil adalah untuk menjadikan perempuan lebih mudah dikenal sehingga mereka tidak diganggu (Sidiq, 2012).

Secara sederhana, perbedaan pendapat ulama tentang aurat dapat dijelaskan sebagai berikut. Pertama, jumhur fuqaha, di antara madzhab-madzhab Maliki, Syafi'i, Ibnu Hazm, Syiah Zaidiah, yang masyhur dari Hanbali dan salah satu riwayat madzhab Hanafi dan Syiah Imamiah yang diriwayatkan dari tingkatan tabi'in seperti Ata dan Hasan Bashri, dan tingkatan sahabat seperti Ali bin Abi Thalib, Aisyah dan Ibnu Abbas berpendapat bahwa: "Hanya muka dan kedua telapak tangan saja yang bukan termasuk aurat bagi kaum wanita." Kedua, Sufyan Ats-Tsauri, salah satu dalam kalangan madzhab Hanafi mengatakan bahwa muka, telapak tangan dan telapak kaki tidak termasuk aurat bagi kaum wanita. Ketiga, salah satu pendapat dalam kalangan madzhab Hanbali dan sebagian Syiah Zaidiah da Zahiri berpendapat bahwa hanya muka saja dari tubuh wanita yang tidak termasuk aurat. Keempat, salah satu riwayat dari Imam Ahmad bin Hanbal dan pendapat Abu Bakar bin Abdurrahman dari 
kalangan Tabi'in mengatakan bahwa seluruh tubuh wanita tanpa pengecualian adalah aurat (Hamidah \& Syadzali, 2016).

Jilbab yang hakiki adalah menutupi seluruh anggota tubuhnya selain wajah dan kedua telapak tangan, tidak keluar rumah dengan berdandan. Terdapat Hijab materi yang berupa penutupan tubuh, dan juga Hijab rohani di mana sosok wanita sebagai manusia ditengah-tengah masyarakat, tidak berusaha tampil dengan dandanan yang menarik perhatian. Pemakaian Jilbab disyari'atkan bagi setiap perempuan muslimah yang sudah akil balig. Cara penetapan syari'at tentang pemakaian Jilbab ini bertahap, ketentuanketentuannya turun secara berangsur sehingga manusia tidak dikejutkan dengan perubahan ketentuan dalam masalah aurat. Jilbab pun seharusnya disesuaikan dengan kriteria Islami yang berupa Jilbab hati yang terpencar dari sifat, perbuatan serta perkataan (Hamidah \& Syadzali, 2016).

Pada zaman sebelum Islam, perempuan Arab yang memakai Jilbab dipandang sebagai wanita baik-baik, walaupun Jilbab pada masa itu hanya menutupi kepala dan rambut yang masih terlihat. Perempuan tanpa jilbab dipandang bermartabat rendah. Adapun Jilbab untuk pria biasanya disebut Burdah atau jubah yang dipakai sebagai pakaian kebesaran atau sebagai pelindung tubuh dari suhu udara maupun debu padang pasir. Setelah kedatangan Islam, Jilbab juga menjadi perintah untuk menutup aurat perempuan.

\section{Sejarah Panjang Jilbab sebagai Identitas Perempuan}

Jilbab muncul sebagai perintah agama yang mengandung ide budaya materi dari Allah s.w.t. melalui firman-Nya untuk penutup aurat perempuan (surah an-Nuur: 31) dan untuk menghindari maksiat bagi yang melihat (surah alAhzab: 59). Berikut kutipan terjemahannya:

\footnotetext{
"Katakanlah kepada wanita yang beriman. Hendaklah mereka menahan pandangannya, dan kemaluannya, dan janganlah mereka menampakkan perhiasannya, kecuali yang (biasa) tampak daripadanya. Dan hendaklah mereka menutup kain kudung ke dadanya, dan janganlah menampakkan perhiasannya kecuali kepada suami mereka, atau ayah mereka, atau ayah suami mereka, atau putra-putra mereka, atau putra-putra suami mereka, atau saudara-saudara lakilaki mereka, atau putra-putra saudara laki-laki mereka, atau putra-putra saudara perempuan mereka, atau wanita-wanita Islam, atau budak-budak yang mereka miliki, atau pelayan-pelayan laki-laki yang tidak mempunyai keinginan (terhadap wanita) atau anak-anak yang belum mengerti tentang aurat wanita. Dan janganlah mereka memukulkan agar diketahui perhiasan yang mereka sembunyikan. Dan bertaubatlah kamu sekalian kepada Allah, hai orang-orang yang beriman supaya kamu beruntung (an-Nuur: 31)."
}

"Hai Nabi, katakanlah kepada istri-istrimu, anak-anak perempuanmu dan istriistri orang mukmin: hendaklah mereka mengulurkan Jilbabnya ke seluruh tubuh mereka (al-Ahzab: 59)."

Tujuan perintah memakai Jilbab adalah untuk menutup aurat pada tubuh perempuan. Menurut Islam aurat perempuan meliputi seluruh bagian 
tubuh kecuali muka dan telapak tangan. Menutup aurat sangat diutamakan bila perempuan berada di luar rumah. Walaupun pada praktiknya, peraturan ketat seperti yang diperintahkan agama Islam kerap dipahami secara longgar oleh sebagian kalangan perempuan muslimah. Selain itu terdapat syarat lainnya yang menyertai Jilbab, yaitu: kain Jilbab menutupi seluruh tubuh kecuali yang boleh ditampakkan, tidak berupa perhiasan yang mewah, tidak tipis, tidak ketat, tidak memakai parfum yang bisa menarik perhatian banyak orang, tidak menyerupai pakaian laki-laki dan tidak menyerupai pakaian orang-orang kafir, tidak menggunakan bahan atau jenis pakaian yang bisa menyebabkan munculnya sifat sombong bagi pemakainya.

Di sini Jilbab sebagai suatu bentuk perintah tuhan memiliki fungsi yang sifatnya sangat teknis. Dalam konteks sosial, Jilbab yang dipakai oleh perempuan muslimah ternyata telah membentuk nilai baru dan mempengaruhi moralitas orang yang melihatnya. Pemakai Jilbab menjadi sangat dihormati dan disegani dalam pandangan normal laki-laki. Hal ini dapat menekan peluang munculnya niat dan perilaku amoral antar lawan jenis. Artinya, ada keselarasan antara perintah tuhan (untuk menutup aurat dan menghindari maksiat) dengan nilai-nilai kesopanan, kehormatan, moral yang muncul dalam praktiknya. Di sini Jilbab sebagai pakaian memiliki fungsi lainnya, yaitu fungsi membentuk identitas sosial bagi si pemakainya.

Agama Islam mulai berkembang di Semenanjung Arab pada abad ke-7. Pengaruh Romawi dan Persia sebagai dua kekuatan imperium besar tidak begitu besar di wilayah itu karena kondisi geomorfologi yang kering, terpencil, terisolasi dan dikelilingi gunung-gunung berbatu dan gurun pasir. Budaya dan tradisi di sana lebih terjaga terhadap pengaruh dari budaya luar. Masyarakat Arab memang dikenal sangat memegang teguh adat istiadat, tradisi, dan doktrin dari leluhur. Dalam konteks sejarah Jilbab, ternyata budaya Arab praIslam sangat mendukung pemakaian Jilbab sebagai perintah baru dalam ayatayat kitab suci yang disampaikan melalui Nabi Muhammad. Kemudian setelah agama Islam berkembang lebih pesat ke luar Semananjung Arab pada abad ke9 sampai 12, proses akulturasi dengan budaya-budaya lokal memperkaya kebudayaan di dunia Islam. Munculnya varian model Jilbab di berbagai daerah adalah salah satu bentuk hasil akulturasi antara agama Islam dan budaya lokal.

Jilbab diperkirakan masuk ke Nusantara seiring proses Islamisasi yang dibawa oleh pedagang dari Arab, Persia, dan India antara abad ke-7 sampai 15. Dalam periode itu agama Islam berkembang sangat cepat dengan ditandai berdirinya kerajaan-kerajaan bercorak Islam di Nusantara. Berlanjut hingga abad ke-19, Jilbab semakin banyak digunakan di daerah-daerah basis muslim, seperti di Sumatera Barat dan tentunya Aceh (Hermawan, 2017). Lebih jauh dalam konteks sosial-budaya, pada sejarawan masih berbeda pendapat mengenai pemakaian Jilbab di Nusantara. Di Jawa abad ke-19 setidaknya masih sedikit sekali masyarakat yang memakai Jilbab sesuai ketentuan dalil, melainkan hanya sebatas selendang yang diselampirkan ke kepala dan dililitkan ke leher. Sebagian pendapat menduga kuat ada hal itu merupakan 
pengaruh dari pola dakwah yang dilakukan para Wali Songo yang dikenal sangat toleran dan adaptif terhadap budaya lokal, terutama budaya warisan Hindu-Buddha yang telah mengakar berabad-abad sebelumnya (Hamidah \& Syadzali, 2016). Sementara itu di kawasan etnik Melayu, Jilbab telah menjadi jati diri bangsa yang tampak dari kekayaan rupa dan motif busana adatnya. Islam dan Melayu lebih tepat dianalogikan seperti dua sisi mata uang. Namun pemahaman dan penerimaan masyarakat di Indonesia terhadap pemakaian cadar yang diasosiasikan dengan kelompok Islam konservatif hingga kini masih menyisakan perdebatan panjang dan fragmentasi kelompok-kelompok Islam.

\section{Reproduksi Identitas Mahasiswi Muslimah}

Respons dan perkembangan Jilbab di Indonesia dapat dirunut dalam beberapa tahap yang dekat sekali dengan kepentingan sosial-politik. Pertama, kontrol Soeharto terhadap penganut agama Islam sejak awal kepemimpinannya sangat berdampak pada kebebasan beragama umat Islam di Indonesia, terutama sebagai dampak traumatik pasca penumpasan gerakan-gerakan separatis seperti DI/TII hingga peristiwa Tanjung Priok. Sikap antipati dan kebijakan represif terhadap potensi perkembangan umat Islam juga menyorot tajam pemakaian Jilbab. Kedua, dekade 1990-an merupakan awal melunaknya sikap dan kebijakan Soeharto terhadap umat Islam. Hal itu ditandai sejak Soeharto mulai lanjut usia dan meningkat religiusitasnya pasca naik haji dan umroh yang diliput oleh pers nasional. Jilbab mulai diperbolehkan digunakan di lingkungan pendidikan. Ketiga, pasca Reformasi yang membuka lebar keran demokrasi, kebebasan berekspresi dan pembaharuan berdampak besar terhadap kemunculan dan kembangkitan kelompok-kelompok Islam yang membawa ideologinya masing-masing. Jilbab mulai menampakkan perkembangannya melalui dakwah dan gerakan Islami di ruang publik, termasuk gerakan dakawah di kampus-kampus. Keempat, kondisi terkini dapat kita lihat bahwa fase perkembangan pemakaian Jilbab telah mencapai puncaknya berikut simbol-simbol dan nilai-nilai baru yang ikut membentuk tren atau budaya pop.

Saat ini Jilbab sering dialihfungsikan hanya menjadi salah satu gaya berbusana agar tampak menarik atau dapat disebut sebagai "Jilbab Gaul". Seperti yang terjadi di lingkungan kita saat ini para perempuan menjadikan Jilbab hanya sebagai salah satu tren dalam berpakaian saja. Di antara faktor-faktor penyebab munculnya tren Jilbab Gaul antara lain:

1) Maraknya tayangan televisi atau bacaan yang terlalu berkiblat ke mode Barat. Faktor ini adalah yang paling dominan semenjak menjamurnya televisi dengan persaingan merebut pemirsa dan menjamurnya berbagai tabloid yang mengumbar mode buka-bukaan ala Barat yang menyebabkan munculnya peniruan di kalangan generasi muda Islam.

2) Minimnya pengetahuan anak terhadap nilai-nilai Islam sebagai akibat kurangnya fungsi jam pendidikan agama di sekolah-sekolah umum. 
3) Kegagalan fungsi keluarga. Munculnya fenomena Jilbab Gaul ini secara tidak langsung menggambarkan kegagalan fungsi keluarga sebagai kontrol terhadap gerak langkah anak-anak muda. Para orang tua telah gagal memberikan pendidikan agama yang benar, parahnya orang tua sendiri cenderung terbawa arus modern (Sidiq, 2012).

Jilbab di Indonesia adalah salah satu bentuk budaya berpakaian perempuan muslimah saat ini. Rahayu mengkaji Jilbab sebagai budaya pop dan identitas muslim Indonesia. Menurutnya, model jilbab dan busana yang digunakan para perempuan muslimah di Indonesia tidak sama dengan di negara-negara Islam lainnya. Hal ini kemudian menjadi ciri khas muslimah Indonesia dalam berjilbab yang telah membentuk identitas sendiri. Sebagai identitas, Jilbab termasuk sebuah konstruksi sosial. Jilbab sekarang dikomodifikasi dan diproduksi massal. Jilbab juga merupakan tindak komunikatif yang relatif mandiri. Hal ini ditandai dari pemakaian Jilbab yang sangat beragam sesuai dengan keinginan pemakainya. Jilbab juga menjadi alternatif atas gaya hidup. Inilah yang dimaksud oleh Rahayu bahwa Jilbab dapat digolongkan sebagai sebuah budaya pop (Rahayu, 2016).

Budaya pop yang disejajarkan dengan budaya massa identik dengan melimpahnya produksi, yaitu melimpahnya industri busana muslim dan ini menjadi sasaran pasar yang menggiurkan. Sebagai contoh, penjual busana muslim cenderung mendominasi pasar tradisional dan mengekspansi bisnis melalui daring atau online shop dan media sosial populer. Selain itu juga dibarengi dengan pesatnya perkembangan tutorial berbagai model dan varian pemakaian Jilbab di YouTube. Para tutor independen yang menjamur di YouTube diuntungkan dengan bayaran dari perusahaan Google berdasarkan jumlah tayangan dan penonton. Dengan demikian, konsumen Jilbab menjadi lebih pintar dan terampil dalam berbusana yang nantinya akan ditampilkan dalam ruang publik yang mendukung kehadiran Jilbab.

Berdasarkan hasil pengamatan terhadap mahasiswi muslimah di kampus UISU dan UIN-SU dapat dijabarkan identitas yang terbentuk dari perilaku pemakaian Jilbab sebagai berikut:

1) Muslimah Fenomenal

Mahasiswi yang diidentifikasi sebagai Muslimah Fenomenal adalah kalangan pemakai Jilbab berukuran lebar (Jilbab Syar'i) yang di kalangan anak muda biasa disebut sebagai Jilbabers. Jilbab Syar'i dipandang oleh masyarakat sebagai simbol kesalehan. Kalangan Jilbabers sangat identik dengan aktivis LDK (Lembaga Dakwah Kampus), "anak masjid", ukhuwah (persaudaraan) yang hangat dan ramah, sopan, pemalu, kearab-araban, dan menyapa dengan panggilan gaya Arab. Jilbabers merupakan representasi kalangan muslimah yang memegang teguh prinsip berjilbab dengan motif teologis. Kalangan ini cenderung tertutup dan bergaul secara berkelompok-kelompok. Cara bergaul demikian didorong oleh keinginan untuk menjaga individu dari pengaruh- 
pengaruh yang tidak baik di lingkungan serta menjaga agar aqidah dan keimanan mereka tidak luntur.

Kelompok ini banyak sekali ditemui di kampus UIN-SU. Selain institusi universitas negeri yang memang berbasis Islam, suburnya organisasi keislaman di UIN-SU juga mempengaruhi langsung besarnya jumlah mahasiswi yang mengikuti jalan hidup mereka menjadi Muslimah Fenomenal. Mereka dapat diintentifikasi mewakili 1 dari 10 mahasiswa dan dapat dengan mudah ditemukan di setiap kelas dan program studi. Selain itu, ada pengaruh dari tradisi seleksi penerimaan mahasiswa baru di UIN-SU pada masa-masa terdahulu, yaitu selama masih berstatus Institut Agama Islam Negeri di mana mahasiswa baru diwajibkan beragama Islam. Perubahan numenklatur dari institut ke universitas yang baru berjalan dua tahun masih konsisten menjaga populasi mahasiswa muslim dan muslimah hingga kini. Sementara di UISU jumlah kelompok ini terbilang cukup jarang. Mereka dapat diidentifikasi mewakili 1 dari 30 mahasiswa dan belum tentu dapat ditemukan di setiap kelas dan program studi. Ada pengaruh status institusi sebagai universitas swasta yang bersifat sangat universal dan notabene sebagai pilihan kedua setelah universitas negeri. Komposisi kelompok mahasiswa di UISU sangat variatif, terdapat pula sejumlah kecil populasi dari kalangan mahasiswa non-Islam.

2) Muslimah Toleran (Moderat)

Mahasiswi yang diidentifikasi sebagai Muslimah Toleran adalah kalangan pemakai Jilbab berukuran sedang. Mereka memiliki ciri "sangat tipikal pelajar", Jilbab dengan model dan lipatan polos dan simpel, berpakaian baju kurung atau kemeja lengan panjang, atau sejenisnya yang dipasangkan dengan bawahan rok atau celana pantalon atau celana kulot. Mereka tidak begitu atraktif dalam hal berpakaian dan biasanya juga dalam hal bersikap. Mereka sangat adaptif dan memiliki kelebihan dapat bergaul dan berinteraksi dengan cair di antara kelompok Fenomenal dan Fashionable. Meskipun tidak begitu memiliki kesan saleh seperti kalangan Jilbabers, namun mereka memiliki kesan lebih beretika ketimbang kalangan Fashionable. Baik dalam hal pandangan agama yang moderat, kelompok ini juga memiliki selera berpakaian dengan motif lebih mengutamakan kenyamanan dan kemauan psikologis ketimbang kesan dan tren di sekelilingnya.

Kelompok ini merupakan mayoritas di kedua kampus, baik UIN-SU maupun UISU. Mereka mewakili mahasiswi dari kalangan ekonomi menengah, modern, casual, sedikit adaptif terhadap tren dan memperhatikan penampilan tetapi tetap mengedepankan etika dan kelayakan di muka umum. Mereka dapat diidentifikasi mewakili 7 dari 10 mahasiswi dan sangat mudah ditemui di mana saja.

3) Muslimah Fashionable

Mahasiswi yang diidentifikasi sebagai Muslimah Fashionable adalah kalangan pemakai Jilbab Gaul. Mereka mengikuti perkembangan mode, juga 
memiliki selera dan perhatian lebih dalam hal berpakaian beserta mengenakan aksesoris dan riasan ketimbang kalangan Muslimah Fenomenal dan Muslimah Toleran. Dari kelompok ini dapat dibedakan lagi menjadi dua tipe, yaitu tipe Syar'i dan tipe Jilboobs. Tipe Syar'i memiliki ciri lebih sopan dengan Jilbab sesuai aturan agama Islam, namun tetap mengupayakan trendy, terkini, mewah, penuh warna, Jilbab berbagai variasi nan modis, dan tetap tetap memiliki kesan Islamis. Mereka terutama adalah konsumen pakaian gamis modis dan "Jilbab kekinian". Tipe ini kebanyakan mewakili muslimah dengan pandangan agama yang lebih moderat dan lentur terhadap pengaruh pemikiran kelompok Islam puritan atau konservatif. Hal demikian tampak dari ambiguitas sikap mereka di antara motif teologis dan modis dalam hal selera berpakaian. Sementara itu tipe Jilboobs memiliki ciri lebih ekspresif dan liberal walaupun tetap muslimah. Pakaian dan Jilbab yang dipakai memiliki kesan sangat atraktif, seperti halnya aksesoris dan riasan yang mendukung penampilan agar percaya diri di muka umum. Padahal nilai barang yang dipakai belum tentu mewah dan modis seperti tipe Syar'i, bahkan cenderung biasa-biasa saja dengan setelan yang tidak jauh dari atasan berupa baju kemeja atau kaos lengan panjang atau mungkin sweater, Jilbab berukuran kecil atau sengaja dibuat minimalis (biasanya model berlipat-lipat dan bersanggul), serta bawahan celana jeans atau bahkan leging ketat sehingga membentuk lekukan pantat, paha hingga kaki. Tipe ini sangat jauh dari kesan saleh namun sangat terbuka dan toleran terhadap kelompok lainnya. Biasanya mereka mewakili muslimah berpandangan agama yang moderat dan liberal atau bahkan sangat awam terhadap agamanya. Pengaruh perilaku imitatif terhadap perkembangan "tren kekinian" dan pergaulan sangat menonjol terhadap pembentukan karakter tipe Jilboobs dari rentang usia remaja dan dewasa. Selain itu, dalam hal interaksi pergaulan juga mereka cenderung sangat cair dan bebas baik kepada sesama perempuan maupun kepada laki-laki di sekitarnya.

Kelompok ini paling banyak ditemui di UISU, terutama tipe Jilboobs yang dapat diidentifikasi mewakili 3 dari 10 orang sedangkan tipe Syar'i terbilang lebih jarang. Sementara itu, populasi mereka di UIN-SU untuk tipe Syar'i masih lebih banyak yang dapat diidentifikasi mewakili 3 dari 10 orang ketimbang tipe Jilboobs yang dapat dikatakan nyaris tidak ada. Kedua universitas memang sangat berbeda dalam hal menerapkan peraturan dan disiplin berpakaian. UINSU lebih ketat dan frontal terhadap tipe Jilboobs serta sangat mengedepankan penyesuaian antara pakaian dan sikap ketika mahasiswa memasuki lingkungan kampus. Berbeda dengan UISU yang secara umum lebih lunak terhadap pakaian mahasiswinya.

\section{PENUTUP}

Menurut hasil penelitian penggunaan Jilbab sebagai representasi simbolik yang dilakukan Eveline Ramadhini (Ramadhini, 2017) ditemukan fakta bahwa penggunaan Jilbab di kalangan mahasiswi merupakan realitas sosial yang sangat kompleks meliputi berbagai aspek sosial. Individu menggunakan Jilbab bukan hanya karena komitmen teologi, melainkan juga karena komitmen 
terhadap kelompok yang dimanifestasikan melalui simbol Jilbab yang mereka gunakan sesuai dengan konstruksi dari pemilik otoritas agama yang terlegitimasi secara sosial. Tidak jauh berdeda, artikel ini mengungkap bahwa dalam perkembangannya, Jilbab merupakan hasil silang budaya yang tecermin dalam busana muslim di Indonesia. Identitas busana muslim di Indonesia tergolong identitas hibrid. Dalam konteks ini, faktor-faktor lokal, regional, dan global saling terintegrasi dan mempengaruhi. Dengan demikian, identitas yang ditampilkan muslim Indonesia adalah identitas hibrid yang memadukan berbagai unsur kebudayaan. Keberadaannya Jilbab selalu menarik untuk diperbincangkan karena berjalin berbagai unsur di dalamnya. Jilbab zaman sekarang merupakan salah satu budaya populer di Indonesia. Baik kelompok Muslimah Fenomenal, Toleran, maupun Fashionable, identitas hibrid yang ditampilkan ditentukan oleh pandangan agama dan motif berpakaian yang dikonstruksi oleh budaya dan lingkungan di sekitarnya. Selain itu, pemakai Jilbab dihadapkan pada negosiasi budaya sekaligus ambivalensi.

\section{REFERENSI}

Ahmadi, D., \& Yohana, N. (2007). Konstruksi Jilbab sebagai Simbol Keislaman. MediaTor, 8(2), 235-248.

Al-Ghifari, A. (2004). Berjilbab tapi Telanjang. Bandung: Muhajid Press.

Berger, P., \& Luckmann, T. (2013). Tafsir Sosial Atas Kenyataan: Risalah tentang Sosiologi Pengetahuan. Jakarta: LP3ES.

Castells, M. (2010). The power of identity. The Information Age Economy Society and Culture (Vol. 2). https:/ / doi.org/10.1002/9781444318234

Hamidah, \& Syadzali, A. (2016). Analisis Semiotika Roland Barthes tentang Fenomena Jilboobs. Studia Insania, 4(2), 117-126.

https://doi.org/10.18592/jsi.v4i2.1124

Hermawan, T. (2017). The Context of Woman's Clothes Verses and It's Influence on the Concept of Woman's Dressing (A Comparison of Four Indonesian Exegeses). Millati, 2(1), 105-123.

https:/ / doi.org/10.18326/ millati.v2i1.105-123

Jenkins, R. (2008). Social identity: Third edition. Social Identity: Third Edition. https://doi.org/10.4324/9780203927410

Rahayu, L. M. (2016). Jilbab: Budaya Pop dan Identitas Muslim di Indonesia. IBDA': Jurnal Kebudayaan Islam, 14(1), 139-155. https:// doi.org/10.24090/ibda.v14i1.2016

Rais, M. A. (1991). Prospek Proses Kebangunan Islam. Bandung: Mizan.

Ramadhini, E. (2017). Jilbab sebagai Representasi Simbolik Mahasiswi Muslim di Universitas Indonesia. Masyarakat: Jurnal Sosiologi, 22(1), 81-103. https://doi.org/10.7454/mjs.v22i1.6835 
Ritzer, G., \& Goodman, D. J. (2003). Teori Sosiologi Modern. Jakarta: Penerbit Kencana.

Sidiq, U. (2012). Diskursus Makna Jilbab dalam Surat al-Ahzab Ayat 59. Kodifikasia, 6(1), 161-183. https:/ / doi.org/10.21154/kodifikasia.v6i1.760

Smith-Hefner, N. J. (2007). Javanese Women and the Veil in Post-Soeharto Indonesia. Journal of Asian Studies, 66(2), 389-420.

https:// doi.org/10.1017/S0021911807000575

Turmudi, E. (2016). The Passion of Jilbab: Socio-Cultural Transformation of Indonesian Muslim Women. International Journal of Scientific and Research Publications, 6(5), 287-292. Retrieved from http:/ / www.ijsrp.org/researchpaper-0516.php?rp=P535374 